\title{
CONSTITUTIONALIZED INTERGOVERNMENTAL AGREEMENTS AND THIRD PARTIES: CANADA AND AUSTRALIA ${ }^{1}$
}

\author{
NIGEL BANKES*
}

\begin{abstract}
Agreements berween two sovereign levels of government are both numerous and significant in modern federal states. Professor Bankes examines the intergovernmental agreements in two such states. Canada and Australia. In particular, he focuses on several concerns: the unintended effects on the rights of third parties arising from the detail of agreements, and the permanence and longevity of constitutional agreements. His investigation raises questions about the wisdom of enshrining intergovernmental agreements with constitutional protection, especially under changing political circumstances.
\end{abstract}

Les accords conclus entre deux gouvernements souverains sont à la fois nombreux et importants dans les états fédéraux modernes. Le professeur Bankes examine les accords intergouvernementaux intervenus entre deux états de ce type. le Canada et l'Australie. Il se penche sur plusieurs questions: l'effet non intentionnel sur les droits des tierces parties découlant des modalités des accords, et la permanence et la longévité des accords constitutionnels. Son examen soulève plusieurs questions sur la sagesse d'accorder une protection constitutionnelle à de tels accords, surtout dans des circonstances politiques changeantes.

\section{TABLE OF CONTENTS}

I. INTRODUCTION ................... 525

II. IDENTIFICATION OF CONSTITUTIONALIZED

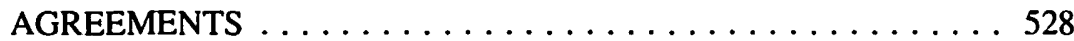

A. INTRODUCTION $\ldots \ldots \ldots \ldots \ldots \ldots \ldots \ldots \ldots \ldots 28$

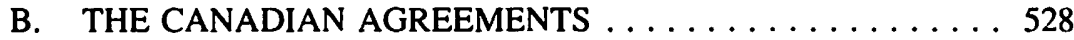

C. AUSTRALIAN CONSTITUTIONALIZED

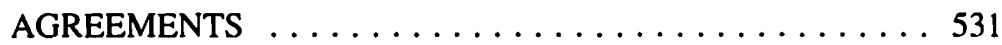

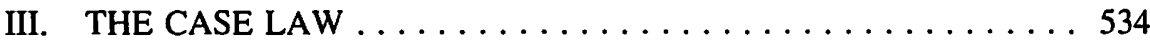

A. THE CANADIAN CASES $\ldots \ldots \ldots \ldots \ldots \ldots \ldots \ldots \ldots$

B. AUSTRALIAN CASE LAW ON THE

FINANCIAL AGREEMENT $\ldots \ldots \ldots \ldots \ldots \ldots \ldots 54$



\footnotetext{
Associate Professor, Faculty of Law, University of Calgary.

This article is part of a larger project on intergovernmental agreements in Canada and Australia. I have dealt separately with the topic of third partics and non-constitutionalized agreements, see $\mathrm{N}$. Bankes, "Co-operative Federalism: Third Parties and Intergovernmental Agreements and Arrangements in Canada and Australia" (1991) 29 Alta L. Rev. 792. That article contains references to the more general literature on intergovernmental agreements. Both articles were completed while I was on sabbatical leave in late 1990 at the Centre for Comparative Studies at the University of Melboume. I would like to thank the Director. Professor Cheryl Saunders, and her staff for their hospitality. I have benefited from the comments of Cheryl Saunders, Susan Blackman. Michael Crommelin. Richard Cullen and an anonymous referec on an carlier draft of this article. I would also like to thank Susan McCormack for her research assistance on this topic many years ago.
} 


\section{INTRODUCTION}

Constitutionalized agreements in one form or another have been used in both Canada and Australia. In Canada these agreements are associated with the creation of a new province or with a significant change in the status of the public lands of an existing province. The agreements have therefore been "constitutionalized" in order to provide a degree of entrenchment and to reflect the permanence of the arrangement. Australia has one example of a constitutionalized agreement in the form of the successive Financial Agreements. In that case, a constitutionalized form was adopted in order to place the details of the arrangements beyond the authority of any particular government to amend and in order to resolve doubts about enforceability.

In recent times governments have contemplated resorting to constitutionalized agreements for several purposes. In Canada, for example, the Government of Newfoundland would like to place its Offshore Accord with the federal government beyond the reach of a potentially hostile federal government. ${ }^{2}$ Similarly, Quebec sought a degree of constitutional protection for immigration agreements that were to be negotiated pursuant to amendments to the Constitution Act, 1867 provided for in the Meech Lake Accord. ${ }^{3}$ In Australia some commentators have suggested that the offshore agreements between the Commonwealth and the states have received a degree of de facto entrenchment as a result of the particular legislative scheme by which they were approved. ${ }^{4}$

A strong analogy can also be drawn between these constitutionalized agreements and aboriginal land claim agreements in Canada. The language of 5.35 of the Constitution Act, 1982 makes it plain that the results of these agreements will be constitutionally entrenched. ${ }^{5}$ A similar status was envisaged for the self-government agreements which were proposed at the 1987 First Ministers' Conference on aboriginal affairs. While these

2. Memorandum of Agreement Between the Government of Canada and the Government of Newfoundland and Labrador on Offshore Oil and Gas Resource Management and Revenue Sharing, 11 February, 1985, s.64, reproduced in Energy Program Reporter (Toronto: CCH Canadian, 1988) para. 67,005 .

3. The amendments were to be made to s. 95 of the Constitution Act, 1867. For the text and commentary see P. Hogg, Meech Lake Constitutional Accord Annotated (Toronto: Carswell, 1988) at 21-25.

4. R. Cullen, "Canada and Australia: A Federal Parting of the Ways" (1989) 18 Fed. L.R. 53 at 77.

5. Constirution Act, 1982, s. 35 (1) "The existing aboriginal and treaty rights of the aboriginal peoples of Canada are hereby recognized and affirmed." "(3) For greater certainty..."treaty rights" includes rights that now exist by way of land claims agreements or may be so acquired." The leading case on the degree of entrenchment afforded by s.35 is Sparrow v. R., [1990] I S.C.R. 1075. 
agreements may not strictly be intergovernmental agreements ${ }^{6}$ there are many similarities and many shared legal problems.

In part the legal problems relate to the status of these intergovernmental agreements. Are they intended to create legal relations or are they intended to represent non-justiciable

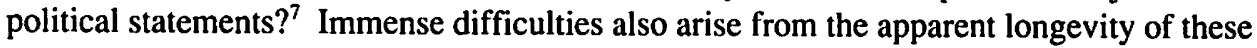
arrangements. For example, the Australian Financial Agreements were developed in very different fiscal circumstances than the present. Borrowing practices have changed dramatically and the Agreements have had a distorting effect on the way in which State governments go to the markets, causing them to use techniques which are hardly consistent with economic efficiency. ${ }^{8}$ Similar issues are also raised by commitments to build and maintain ferry and railroad services which form such an important part of constitutionalized agreements in Canada.

These important issues however are not the main concern of the present paper which focuses on the effect of constitutionalized agreements on third parties. There can be little doubt but that the primary purpose of these agreements is to bind governments themselves and avoid common law doctrines which cause difficulties for non-constitutionalized agreements; doctrines such as sovereignty of parliament and restrictions on fettering the discretion of the executive. However, many of these agreements (especially in Canada) have also had important incidental or intended effects on the rights of individuals or particular classes of individuals.

A second concern of the paper is with the longevity of constitutionalized agreements. While one expects constitutions to be enduring insofar as they deal with the allocation of legislative and executive power and entrench fundamental rights, freedoms and values, it is less clear that all of the matters dealt with in intergovernmental agreements (e.g. specific types of transportation links) should be entitled to perpetual protection.

The extent to which individuals may be affected by these agreements flows from two factors. First, a constitutionalized agreement constitutes a limitation on legislative power if it cannot be unilaterally amended. Its effect on individuals depends upon the scope of this limitation on power which in turn depends upon the actual provisions of the agreement. At its most basic, the limitation on power will only preclude the unilateral legislative repudiation of the agreement. The limitation on power will be more extensive if the agreement can be interpreted as extending rights or immunities to third parties. An

6. One constitutionally protected land claim agreement is also a full intergovernmental agreement since both Quebec and Canada are party to the James Bay and Northem Quebec Agreement with the James Bay Cree and the Northern Quebec Inuit: see further the recent decision on the James Bay and Northem Quebec Agreement, Re Cree Regional Authority v. Canada (Federal Administrator) (1991), 81 D.L.R. (4th) 659 (F.C.A.).

7. This has been of particular concern in Australia, see for example The State of South Australia v. The Commonwealth (1962), 108 C.L.R. 130 (H.C.A.).

8. C. Saunders, "Government Borrowing in Australia" (1989) 17 M.U.L.R. 187. 
example would be the claim that a resident of Prince Edward Island might have a justiciable entitlement to a ferry service which could be maintained against the Government of Canada.

Second, a third party will be indirectly affected by the extent to which a constitutionalized agreement transfers legislative power from one government to another. The most obvious examples of this would be the Terms of Union of the various provinces of Canada which created a federal state where there was formerly a unitary state.

Two other ways in which a third party will be affected by a constitutionalized agreement do not depend upon the constitutionalized nature of the arrangement. A third party may be affected if the agreement itself, by virtue of its statutory approval, constitutes law. This is a feature shared with other non-constitutionalized agreements which are given the force of law by statute. Much will depend upon the specific language of the statute. ${ }^{9}$ Additionally, third parties will be affected if a constitutionalized agreement effects a transfer of property. In part this flows from general principles of property law but in part it also flows from the fact that certain heads of legislative power are dependent upon title. In Canada, $\mathrm{s.9l}(1 \mathrm{~A})$ as a head of legislative jurisdiction speaks to the public property of the Dominion ${ }^{10}$ whilst $s .92(5)$ is concerned with the public property of the province. ${ }^{11}$ In Australia, the Commonwealth has exclusive legislative jurisdiction over Commonwealth places with the result that state laws do not apply of their own force. ${ }^{12}$

The remainder of the paper is laid out in the following manner. The first part is concerned to identify the constitutionalized agreements which each country has adopted, and in the second the limited case law is described and analyzed. The focus of the paper is the effect of these agreements on third parties. The main thesis which emerges is that constitutionalized agreements may have far-reaching consequences for third parties which in many cases cannot have been intended by the drafters. This should not lead us to

9. See L. Warnick, "State Agreements - the Legal Effect of Statutory Endorsement" (1982) 4 A.M.P.L.J. 1 and cases cited in note 115 , infra. The issue is also important for aboriginal land claim agreements. In what circumstances, if at all, may they bind third parties? It is clear that only aboriginal people may claim constitutionally protected rights but what of other aspects of these agreements which are generally given some form of statutory sanction? See, for example, Western Arctic (Imuvialuit) Claims Settlement Act, S.C. 1984, c. 24, s. 3(1) "The Agreement is hereby approved, given effect and declared valid." See further the recent decision on the James Bay and Northern Quebec Agreement, supra, note 6. See generally, G. La Forest, Natural Resources and Public Property under the Canadian Constitution (Toronto: University of Toronto Press, 1969).

11. In this sense a non-constitutionalized agreement may well have an important constitutional effect. See for example A.G. of Canada v. Highie, [1945] S.C.R. 385, and Gardner v. R. in right of Omario (1984), 45 O.R.(2d) 760 (H.C.).

12. Worthing v. Rowell and Muston Pty. Lud. (1970), 123 C.L.R. 89 (H.C.A.). In Canada the results of a transfer are not as dramatic for provincial laws of general application continue to apply: Construction Montcalm Inc. v. The Minimum Wage Commission, [1979] 1 S.C.R. 754. 
avoid the use of intergovernmental agreements, but it should cause us to submit proposals for entrenching any of these agreements to careful scrutiny.

\section{IDENTIFICATION OF CONSTITUTIONALIZED AGREEMENTS}

\section{A. INTRODUCTION}

A constitutionalized agreement is an agreement which is given a special status by the constitution. This must mean more than that the negotiation and conclusion of the agreement is authorized by the constitution. Rather, we mean that the agreement actually becomes an entrenched part of the constitution ${ }^{13}$ or that the constitution prescribes its normative effect. Either way the agreement will act as a limitation on power as between the parties (government $\mathrm{A}$ will be unable to repeal its obligations to government $\mathrm{B}$ unilaterally) or in favour of other persons. (Government A cannot, without the consent of government B, interfere with the rights or privileges accorded to citizens or group $\mathrm{C}$.)

Up to a certain point the identification of these agreements is straightforward. Two formulations have been used in Canada ${ }^{14}$ and a third, quite different formulation, in Australia.

\section{B. THE CANADIAN AGREEMENTS}

In Canada some clarification of which agreements are constitutionalized is provided by s. 52 of the Constitution Act, 1982 which states that "The Constitution of Canada includes ... the Acts and Orders referred to in the Schedule...." The constitutional documents listed in the schedule include the various Terms of Union and the Constitution Acts of 1930 and 1949. In keeping with the traditions of a Constitution that is part written and in part unwritten it is clear from the word "includes" that the list is not exhaustive.

In the case of the Terms of Union of the provinces of British Columbia ${ }^{15}$ and Prince Edward Island, ${ }^{16}$ constitutional status is provided by s. 146 of the Constitution Act, 1867 which states that an Imperial Order in Council approving terms agreed to by the

By the term entrenched I mean that the agreement could not be changed by mere legislation of one government but would need to comply with one of the amending formulae found in ss. 38, 41 (c), 42 or 43 of the Constitution Act, 1982, in the case of Canada or s. 128 in the case of Australia. The possibility of "manner and form" entrenchment is discussed, infra, note 37.

14. In addition to the two formulations described in the text,reference might also be had to $s .35$ of the Constitution Act, 1982 which accords constitutional protection to treaties and land claim agreements. The rights contained within these agreements are not themselves made a part of the Constitution, s.35 along with s.52, merely prescribes the degree of entrenchment which they are accorded. All the consequences of this distinction are not at present clear. One consequence must be that such agreements are not subject to the amending formulac of Part V of the Constitution Act, 1982.

15. R.S.C. 1985, Appendices, Appendix II, No. 10.

16. R.S.C. 1985, Appendices, Appendix II, No. 32. 
provincial legislatures and the Houses of Parliament of Canada and "the Provisions of any Order....shall have effect as if they had been enacted by the Parliament of the United Kingdom of Great Britain and Ireland." That form of words collapses two quite distinct concepts. First, it grants entrenched constitutional status to the agreements for they take effect as an Act of the Imperial Parliament. Second, the agreements are law, because they are stated to have the same effect as a statutory enactment. ${ }^{17}$ The actual language of the Order in Council in each case indicates that "the said Colony ... shall be admitted ... upon the terms and conditions in the hereinbefore recited Addresses." The separate Addresses of the Senate, the House of Commons and the Legislative Council of the Colonies were scheduled to the Order in Council and recited the terms under which each colony was prepared to enter into Union, which terms were agreed upon by delegates of the respective Colonies and the Dominion.

These same two consequences, that is, entrenchment and status as law, flow just as surely from the formulation used for the prairie provinces' Natural Resources Transfer Agreements (NRTAs). In these, constitutional status was accorded by the Imperial Constitution Act, $1930^{18}$ which stated that "The agreements set out in the Schedule to this Act are hereby confirmed and shall have the force of law notwithstanding anything in the British North America Act..." "Law" in this case must mean Imperial law. The prairie agreements also provide that they may be amended by concurrent statutes of Canada and the province concerned and it has been assumed that any subsequent agreement ratified in this way is also constitutionally entrenched. ${ }^{19}$

17. In addition to the cases cited in the subsequent sections dealing with individual agreements see $A . G$. Newfoundland v. Churchill Falls (Labrador) Corporation (1985), 168 A.P.R. 91 (Nfld. C.A.), aff'd [1988] 1 S.C.R. 1085, Canadian Northern Pacific Railway Company v. Corporation of New' Westminster, [1917] A.C. 602 (P.C.), Director of Aboriginal and Islanders Advancement v. Peinkinna (1978), 52 A.L.J.R. 286 (P.C.).

The agreements were actually approved by federal and provincial legislation as well as an Imperial statute leading the Privy Council in A.G. Alberta v. West Canadian Collieries Ltd., [1953] A.C. 453 at 455, per Lord Asquith to say that the Alberta agreement in that case was given "triple statutory force." Legally the federal and provincial statutes do not seem to have been necessary except as a domestic ratification of the proposal before it could be dispatched to Westminster. P. Gerin-Lajoie, Constitutional Amendment in Canada (Toronto: University of Toronto Press, 1950) at 91-93.

19. It may be argued that the amending formula in the agreement must be taken to have been replaced by the formulae contained in the Constitution Act. 1982. Part V. This argument has been contested by one reviewer of this paper. While it is true that under s. 52(3) an amendment to the Constitution need only comply with the Constitution (and not specifically Part $V$ thereof), my argument, (which ultimately has to be based upon an implied repeal) turns upon (a) the claim that Part V is intended to provide a complete code governing amendments to the Constitution of Canada and (b) the use of the word "only" in s. 43 . Section 43 deals with provisions of the Constitution which apply to "one or more, but not all, provinces" and goes on to say that a proclamation effecting the amendment may be issued "only where so authorized" by resolutions of the legislatures of the affected provinces and of the Senate and House of Commons. The word "only" (and the French text is perhaps clearer on this point) could be read as meaning "and in no other way." I accept that that might be a strained interpretation but it is clear that the draftsperson wished to avoid a situation in which, for example. an NRTA could be amended under s. 38(1) without the consent of the province most concerned (see S. Scott, "The Canadian Constitutional Amendment Process" (1982), 45 Law and Contemp. Prob. 249, esp. at 254 and 276). I prefer to rely on the more general claim that Part V was intended to 
Essentially the same formulation was adopted by the Imperial Constitution Act, 1949 admitting Newfoundland into Confederation. ${ }^{20}$ In the case of Newfoundland, the Terms of Union take the form of a memorandum of agreement between the representatives of Canada and Newfoundland which was subsequently approved by the Parliament of Canada, the Government of Newfoundland and the majority of the people of Newfoundland in a referendum.

A list of constitutionalized agreements for Canada would therefore include the Terms of Union, the Transfer Agreements, and any amendments, at least to the Transfer Agreements. What though of amendments to the Terms of Union, such as the famous agreement of 1883-84 between British Columbia and Canada amending the railway clause of the Terms, or the myriad agreements relating to Article 13 dealing with Indians and Indian reserves. ${ }^{21}$ Are these constitutionalized? Section 52 of the Constitution Act provides only limited assistance. None of the amendments to the NRTAs or the agreements just mentioned are listed in the schedule. Instead para. 52(2)(c) states that "any amendment to any Act or order" included in the schedule is also part of the Constitution. But what constitutes "an amendment to an order"?

The constitutional status of the railway settlement agreement seems to have been assumed in the past, ${ }^{22}$ and expressly accepted in one recent decision of the British

provide a complete code. The real significance of the difference between the two amending formulae is found in $\mathrm{s}$. 47 which provides that in some circumstances a $\mathrm{s} .43$ proclamation might be made without the concurrence of the Senate. It is therefore a less rigorous amending formula than that found in the NRTAs.

In Re Stony Plain Indian Reserve No. 135, [1982] 1 W.W.R. 302 at 329-330, the Alberta Court of Appeal cast some doubts upon the ambit of the original amending procedure suggesting that some amendments would infringe the A.G.N.S. v. A.G. Can., [1951] S.C.R. 31. I would argue that this was mistaken and that that doctrine has no application where the governments concerned comply with a constitutional amending formula. The only limitation I would accept is that the amendment would have to constitute an amendment to a "provision" of the agreement. There may be doubts about some of the purported amendments. See the agreements of 28 March 1941, S.C. 1941, c.22 and the agreement of 25 September 1945, S.C. 1945, c. 10.

30. Section 146 could not be utilized because Newfoundland did not at the time have a competent legislature: In re Bowater's Newfoundland Pulp and Paper Mills Limited, [1950] S.C.R. 608 at 649 per Estey J., and at 659, Locke J.

21. See Moses et al. v. R. in right of Canada, [1977] 4 W.W.R. 474 (B.C.S.C.), aff'd [1979] 5 W.W.R. 100 (B.C.C.A.), authority questioned in A.G.B.C. v. Andrew and Moumt Currie Indian Band. [1991] 4 C.N.L.R. 3 (B.C.C.A.), and Dunstan v. Hell's Gate Enterprises Lid. (1985), 22 D.L.R.(4th) 568 (B.C.S.C.), rev'd on the facts (1987), 45 D.L.R. (4th) 677 (B.C.C.A.). N. Bankes, "Indian Resource Rights and Constitutional Enactments in Western Canada, 1871-1930" in L. Knafla, ed. Law and Justice in a New Land: Essays in Western Canadian Legal History, (Calgary: Carswell, 1986) at 129-164. For a consideration of similar issues in the context of interjurisdictional water agreements see J. Saunders, Interjurisdictional Issues in Canadian Water Management (Calgary: Canadian Institute of Resources Law, 1988) at 89-91.

22. Atrorney General British Columbia v. Attorney General Canada (1886), 14 S.C.R. 345, rev'd (1989) 14 A.C. 295 (P.C.), hereinafter the Precious Metals Case. 
Columbia Supreme Court ${ }^{23}$ without reference to s.52. However, the point is not free from doubt as it seems to have been assumed to the contrary in the judgements of both the Privy Council and the Supreme Court of Canada in Esquimalt and Nanaimo Ry. Co. v. A.G.B.C. ${ }^{24}$ The question at issue there was whether the company could be said to have a contractual entitlement to a tax exemption which was contained in the provincial legislation ratifying the railway settlement agreement. The Supreme Court was prepared to find such a right; the Privy Council disagreed but all members simply assumed, and in some cases expressly stated, ${ }^{25}$ that the only issue was the contractual issue. The province, it was said, had an undoubted power to repeal the exemption. Indeed the potential constitutional issue was simply not argued. Part of the explanation for this may be that the case came on as a reference which did not raise the question directly, and another part no doubt turns on the fact that the exception was contained in the provincial ratifying legislation rather than the agreement itself.

Difficult questions are also posed by the agreements dealing with the status of Indian reserves in British Columbia. These agreements are related to the Article 13 obligations of the Province, but they do not purport to be amendments to that Article. ${ }^{26}$ Such authority as there is tends to support the view that these agreements do not affect the rights of third parties because they are not creative of law. ${ }^{27}$ It would not follow from that, however, that they were not constitutionally entrenched and therefore capable of being overridden by the unilateral action of either party. ${ }^{28}$

\section{AUSTRALIAN CONSTITUTIONALIZED AGREEMENTS}

The only Australian agreements which have constitutional effect are the financial agreements which are supported by s. 105A of the Constitution. We shall deal with the substance of that section below; attention is drawn here to the formulation that the parties chose to adopt to give the agreements constitutional effect. This is found in subs.(5) which provided that the agreements as varied "shall be binding upon the Commonwealth and the States parties thereto notwithstanding anything contained in this Constitution..." Hence, the agreements did not become part of the Constitution but their overriding constitutional effect was prescribed.

Attorney General of British Columbia v. Attorney General of Canada (1989), 42 B.C.L.R. (2d) 339 (B.C.S.C.); aff'd on this point by the Court of Appeal (1991), 59 B.C.L.R. (2d) 280 esp. at para. 67 and pp. $300-08$.

24. [1948] S.C.R. 403, rev'd [1950] A.C. 87 (P.C.).

2s. Ibid. Rand J. at 440.

26. For a review of these agreements see Bankes, supra, note 21. For an example see British Columbia Indian Lands Settlement Act, S.C. 1920, c.51 and Indian Affairs Settlement Act, S.B.C. 1919, c.32.

27. Dunstan v. Hell's Gate Enterprises Ltd. (1985), 22 D.L.R.(4th) 568 (B.C.S.C.) at 594-5 and 597, rev'd on the facts (1987), 45 D.L.R.(4th) 677 (B.C.C.A.)

28. The distinction lies at the heart of Sankey v. Whirlam (1978), 142 C.L.R. 1 (H.C.A.), discussed in detail infra. 
In addition to the Financial Agreements, however, mention should also be made of the Australian Offshore Agreement which is designed to achieve a measure of de facto if not de jure constitutional entrenchment. As in Canada, ${ }^{29}$ the Australian offshore settlement followed the success of the federal government in court. There are basically two elements ${ }^{30}$ to the complex arrangement of 1979 which constitute the offshore settlement. First, the Coastal Waters (State Title) Act (Cwth) transfers title to a 3 mile territorial sea to the states without amending the boundaries of the states. ${ }^{31}$ Second, in order to confirm $^{32}$ the power of the states to legislate extra-territorially for this area and other offshore waters, the Commonwealth, at the request of the states and pursuant to s.51(xxxviii) of the Australian constitution, ${ }^{33}$ passed the Coastal Waters (State Powers) Act, 1980.

The constitutionalized effect of these arrangements depends upon two arguments. The first is primarily pragmatic; any repeal of the State Title Act might engage s.51(xxxi) of the Australian constitution and therefore require the Commonwealth to pay "just terms" although what that might amount to is a matter of some debate. ${ }^{34}$ Second, it has been suggested that the State Powers Act might not be repealable in the absence of a request from the states because legislation under $\mathrm{pl}$.(xxxviii) must comply with the manner and form prescribed, namely a request from the states. Dr. Cullen has considered the arguments both ways on this point ${ }^{35}$ and has concluded that the State Powers Act probably is not entrenched in this way and it certainly cannot preclude the Commonwealth undoing the effect of the statute by legislating in reliance on its external affairs power. In effect this argument simply denies that there is special protection for Acts passed pursuant to pl.(xxxviii) which could also be justified under any other head of power. Doubts still remain as to whether any other head of power would be available. Obviously these arguments, whether right or wrong, do not touch the de facto protection accorded to the State Title Act, by virtue of the potentially very high costs of reacquisition.

See C. Hunt, The Offshore Petroleum Regimes of Canada and Australia (Calgary: Canadian Institute of Resources Law, 1989).

See Cullen, supra, note 4.

Thus avoiding the need to comply with the referendum requirements of s.123 of the Australian Constitution.

The High Court has since ruled that this legislation was not necessary for at least some of the states' legislation. Extra-territorial state legislation will be upheld, in the absence of an inconsistency with federal law, so long as there is some link with the state: Port MacDonnell Professional Fishermen's Association Inc. v. The State of South Australia (1989), 168 C.L.R. 340 (H.C.A.) at 372, following Union Steamship Co. of Australia Pty. Lid. v. King (1988), 166 C.L.R. I at 14 (H.C.A.).

3. This provides that Parliament has power to make laws with respect to "The exercise within the Commonwealth, at the request or with the concurrence of the Parliaments of all the States directly concemed, of any power which can at the establishment of this Constitution be exercised only by the Parliament of the United Kingdom..."

Section 51 (xxxi) provides that Parliament has power to make laws with respect to "The acquisition of property on just terms from any State or person for any purpose in respect of which the Parliament has power to make laws." See Cullen, supra, note 4 at 104-105.

Ihid. at 96-100. 
Consideration of the Australian offshore arrangements does invite the question of how one might construct a constitutionalized agreement in the de iure sense. In Australia the model of s.105A presents one alternative but that would require a full constitutional amendment under s.128 of the Constitution unless the agreement fell within the existing description of s.105A, that is an agreement "with respect to the public debts of the States."

In Canada the answer would have to be found in Part V of the Constitution Act, 1982. Suffice it to say that in most cases the bilateral amending procedure found in $\mathbf{s . 4 3}$ would probably not be available because it refers to an amendment of any "provision" of the Constitution "that applies to one or more, but not all, provinces."

Short of amending the Constitution however, it might be argued that a measure of entrenchment could be achieved by a manner and form requirement applied to local and federal statutes endorsing an intergovernmental agreement. ${ }^{37}$

This formula might be used to amend existing constitutionalized agreements. Scott, supra, note 19 , considers that it might have a wider ambit.

37. See George Winterton, "Can the Commonwealth Parliament Enact "Manner and Form" Legislation?" (1980) 11 Fed. L.R. 167. Winterton takes the view that a state could pass manner and form legislation. This argument is based on general principles and the provisions of the Colonial Laws Validity Act. Clear language will be necessary and the matter cannot be considered to be free from doubt. West Lakes Limited v. South Australia (1980), 25 S.A.S.R. 389 (S.A.S.C.), esp. per King C.J. at 397, and Commonwealth Aluminium Corporation v. A.G., [1976] Qd. R. 231 (S.C.Q.). (By analogy with the relationship between the U.K. Parliament and Europe it may be argued that the manner and form requirement might extend to adding an element to the existing legislature.) The position is much more complex for the Commonwealth. Here Winterton takes the view that the Commonwealth Parliament could enact a form requirement (e.g. a requirement that a statute be expressly overruled). In his view this is implicit in the power of Parliament to make laws under 5.51 of the Australian constitution. A manner requirement which proposed special majorities would infringe ss. 23 and 40 and a substituted legislature would infringe s.1. Finally, he argues that an altemative legislature (e.g. a statute providing that an Appropriation Act could become law without the consent of the Senate) would be permissible and would not infringe either s.128, s.53 or s.57.

It is interesting to note that the Australian Co-operative Companies and Securities Scheme stopped short of a formal manner and form requirement but did provide ( $\mathrm{s} .47$ ) that the Commonwealth would not submit to Parliament any legislation which would amend the scheme without the consent of the states expressed through the Ministerial Council. No doubt this would be entirely unenforceable: South Australia v. Commonwealth (1962), 108 C.L.R. 130 (H.C.A.). The Agreement is scheduled to the Commonwealth and State Acts implementing the arrangement, and is also reproduced in Howard, The Co-operative Companies and Securities Scheme, Information Paper 4, Intergovernmental Relations in Victoria Program, Law School University of Melbournc, 1982.

The position of the states would not appear to have been changed in this regard by the passage of the Australia Act which repealed the Colonial Laws Validity Act in so far as that Act applied to the states. The new Act contains a section worded in terms which are almost identical to the Colonial Laws Validity Act. The new statute takes its authority from s.51 (xxxviii) of the Constitution, quoted supra, note 33.

In my view some manner and form requirements for both federal and provincial legislation would be upheld by Canadian courts. See Mercure v. A.G. Saskatchewan, [1988] I S.C.R. 234; R. v. Drybones, [1970] S.C.R. 282 and Singh v. Minister of Employment and Immigration, [1985] I S.C.R. 177, Beetz J. at 239. However, manner and form requirements that added an element to the 
We shall now turn to consider the case law on these various constitutionalized agreements bearing in mind that our primary concern is the way in which they affect third parties, and that our secondary concern is with the longevity of some of the details of the agreements.

\section{THE CASE LAW}

\section{A. THE CANADIAN CASES}

\section{The British Columbia Terms of Union}

Of the three Terms of Union, British Columbia's has been the most litigated both by governments themselves and by third parties. The governmental litigation has implications for third parties for it has been concerned in large part with property questions, with the result that some third-party titles have been confirmed and others nullified depending upon whether a grant originated with the Crown in right of the province or in right of Canada. The litigation has concentrated on two Articles of the Terms of Union; Article 11 the railway clause, and Article 13 which deals with Indians and Indian reserves.

\section{(a) The Railway Belt Litigation}

Under the terms of the railway clause the Dominion was required to secure the commencement and completion of the Pacific railway within ten years of the Union. This was not achieved, and between 1871 and 1883 there was a continuous and serious dispute between the parties. A settlement was ultimately arrived at in 1883 and implemented by reciprocal legislation. As part of the agreement, the province agreed to transfer public lands to the Dominion in trust to be used to further the construction of the railroad. The first case interpreting the settlement agreement was the Precious Metals ${ }^{38}$ case. Third party rights were not at issue here but the decision is of importance because the case effectively established the interpretive approach that the courts would take to constitutionalized agreements. The formal issue for determination was whether or not the prerogative right to the precious metals passed to the Dominion Crown along with the public lands in the railway belt that had been transferred to the Dominion. The majority of the Supreme Court held that the law of Crown prerogative had no application to a transaction "of the nature of a treaty between two independent bodies" ${ }^{39}$ "giving effect

legislative process which involved the other level of government might well be inconsistent with the interdelegation cases: A.G. Nova Scotia v. A.G. Canada, [1951] S.C.R. 31. For a recent discussion see R. Elliot, "Rethinking Manner and Form: From Parliamentary Sovereignty to Constitutional Values" (1991) 29 Osg. Hall L.J. 215. A manner and form argument was mounted by one of the interveners in Reference re Canada Assistance Plan (1990), 46 B.C.L.R. (2d) 273 (B.C.C.A.), rev'd (1991), 58 B.C.L.R. (2d) I (S.C.C.) at 27-29. Sopinka J. cited with approval the West Lakes case, supra, note 37.

38. Supra, note 22.

39. Ibid. at 372, Gwynne J. 
to and carrying out the constitutional compact. ${ }^{40}$ The Privy Council however rejected the treaty analysis. They did not question the justiciability of this "general statutory arrangement" but preferred to see it as an agreement which "embodies the terms of a commercial transaction." ${ }^{41}$ Since prerogative powers were not specifically mentioned they did not pass to the Dominion. In reaching this conclusion the Privy Council was emphasising the status of the agreement as a private rather than as a public transaction.

Unlike the decision in Precious Metals, the Privy Council's decision in Burrard Power v. $R{ }^{42}$ showed that the Terms had serious implications for third parties. The federal Attorney General sought to question the validity of a provincial grant of water rights within the area of the railway belt. The Privy Council upheld the claim on the basis that the transfer of public lands must have contemplated the transfer of water rights and the concomitant power to regulate those rights. Contemporary commentators noted that this decision wrought havoc on the water rights of subjects within the dry belt. ${ }^{43}$ The case illustrates very vividly that the Terms of Union were more than just a private law transaction. The transfer differed in a fundamental way from a similar transaction with a citizen because regulatory powers were also held to pass even though not specifically mentioned in the agreement. Although these two decisions of the Privy Council are reconcilable at a technical level the latter recognizes the governmental nature of the transaction while the former does not.

At the time of writing, British Columbia is interpreting widely the obligations of the Dominion under the railway clause and the associated agreements of 1883-84 and is arguing that Canada has a perpetual obligation to maintain a passenger and freight service from Victoria to Courtenay on Vancouver Island. So far the claim has been established at trial and in the Court of Appeal in relation to the Victoria-Namaimo section of the line. $^{44}$ The case does not raise directly a third-party issue but the province has also commenced parallel administrative law proceedings ${ }^{45}$ in which it has been joined as

4.5 .

Ibid. at 358, Ritchie C.J.

Supra, note 22 at 304. For a similarly strict interpretation see Esquimalt and Nanaimo Ry Co. v Treat, [1919] 3 W.W.R. 356 (P.C.); but see the C.A.'s interpretation of this case in A.G.B.C., supra, note 23 at $302-04$.

(1910), 43 S.C.R. 27, [1911] A.C. 87 (P.C.).

See Carson, Report on Railway Belt Hydrographic Survey for 19/1-12. Canada, Sessional Papers, 1914 n.25f, esp. at 17-31. See also The Queen v. Farwell (1887), 14 S.C.R. 392, the Attorney General of Canada succeeded in an action commenced by writ of intrusion against a provincial Crown grantee of land within the railway belt. The Crown could point to no paper title other than the federal provincial agreement but this sufficed. Strong J. (at 425 ) referred to the provincial ratifying legislation as "self executing" and Gwynne J., harking back to his judgement in the Precious Metals case, stated (at 428): "the title of Canada is referable to the treaty alone, and the acts of Parliament which were passed to carry out the provisions of that treaty."

44. Supra, note 23. The trial judge held (at 362 ) that not only does the agreement have constitutional force but that it also is part of the provincial statute.

Re an Act Respecting Vancouver Island Railway and four other statutes (1990), 69 D.L.R. (4th) 217 (B.C.S.C) also aff'd by the C.A., supra, note 23 at 322-33. This is effectively a rerun of earlier litigation questioning the jurisdiction of the Canadian Transpon Commission to determine whether 
plaintiff by several municipalities. In the action the parties are contesting the ability of the Governor General, acting under the National Transportation Act, to make an order discontinuing passenger service on the island railway. Putting the question of standing aside for the present, the parallel proceedings do invite the question whether an affected municipality could also have obtained a declaration in the constitutional case.

As has already been noted, an opportunity to consider whether a third party might claim rights under the railway agreement as a constitutional document was missed in Esquimalt and Nanaimo Ry. Co. v. A.G.B.C. ${ }^{46}$ The argument would simply have been that the agreement, to which the company was not a party, constituted a limitation on the power of the provincial legislature. As the case was actually argued, it seems to have been assumed that the various agreements lacked any constitutional status. The company failed to establish a contractual right to the exemption because, in the opinion of the Privy Council, there was no contractual nexus between the province and the contractors and because the province owed no trust-like duties to the company. Both courts simply assumed that the agreement did not impose a limitation on power but the issue did not have to be dealt with because of the form in which the reference questions were posed. ${ }^{47}$

\section{(b) The Article 13 Litigation}

In addition to the rich case law on the railway belt clause and associated agreements, there has also been litigation on Article 13 which raises the question of third-party rights very directly. The litigation has focused upon Article 13 as a limitation on federal legislative power and bears obvious similarities to the much more extensive litigation on the Indian-hunting clauses of the NRTAs discussed below. Article 13 provides in part that:

The charge of the Indians, and the trusteeship and management of the lands reserved for their use and benefit, shall be assumed by the Dominion Government, and a policy as liberal as that hitherto pursued by the British Columbia Government shall be continued by the Dominion Government after the Union.

The leading case is Jack v. $R .^{48}$ in which the accused sought to rely upon Article 13

the passenger service was economic: Re Attorney General of British Columbia and Canadian Pacific (1981), 131 D.L.R.(3d) 690 (F.C.A.). A question was argued as to the standing of the province to raise the issue but it was resolved in the province's favour, albeit not very conclusively.

47. It needs to be emphasized, as noted earlier, that the exemption from tax was found in the provincial legislation rather than the agreement. This was not a case where the agreement was to take effect as if enacted in the statute. Consequently, the argument would have had to have taken the form that the section in the provincial statute was entrenched. Although this complicates the argument the critical point would be that the package as a whole must be seen as an amendment to a constitutional provision and, as such, entitled to constitutional protection.

48

[1980] 1 S.C.R. 294, followed in R. v. Adolph (1984), 3 D.L.R.(4th) 291 (B.C.C.A.). The decision in Jack must be taken to have overruled an earlier decision on Article 13, R. v. Point (No. 2) (1957). 22 W.W.R. 527 (B.C.C.A.). Both this case and Geoffries v. Williams (1959), 16 D.L.R. (2d) 157 
as a defence to a charge under the federal Fisheries Act arguing that federal fisheries policy was less liberal than that of the old colonial administration. He failed on the merits but the Crown had argued that he was not entitled to rely on Article 13. Laskin C.J. rejected that argument. In his view there was a distinction to be made between those intergovernmental agreements with constitutional status and those without. A third party could always rely upon a constitutionalized intergovernmental agreement. ${ }^{49}$ Inferentially one can also read the case as supporting a liberal, constitutional approach to the interpretation of the agreement rather than a narrow, commercial approach.

\section{The Prince Edward Island Terms of Union}

There are no reported decisions dealing directly with a claim of a third party based upon the Prince Edward Island Terms of Union. However, there are some interesting dicta in the most important reported decision on the Terms. This deals with an action by the province against the federal government for disruption of the ferry service between the Island and the mainland. Under the Terms of Union, the federal government obligated itself to provide a ferry service to the Island. ${ }^{\text {so }}$ The scope of the obligation had been a matter of dispute in the past ${ }^{51}$ but in 1973 the ferry service was disrupted by a nationwide strike. The province commenced an action in federal court ${ }^{52}$ seeking damages for breach of the obligation. The province was only partially successful at trial, Cattanach J. holding that there was a breach of a statutory duty ${ }^{53}$ but no entitlement to damages.

(B.C. Co.Ct.) which raised Art. 13 of the Terms of Union in a very tentative manner, are discussed by K. Lysyk, "The Unique Constitutional Position of the Canadian Indian" (1967) 45 Can. Bar Rev. 513 at 522 .

49. Ibid. at 299.

so. The actual language was that Canada would establish and maintain an "efficient steam service for the conveyance of mails and passengers between the island and the mainland of the Dominion, winter and summer thus placing the Island in continuous communication with the Intercolonial Railway and the railway system of the Dominion."

31. For an unsympathetic review of the earlier provincial claims which were settled by agreement see J.A. Maxwell, Federal Subsidies to Provincial Governments in Canada (Cambridge: Harvard University Press, 1937) at 72-74, and 105-106. Maxwell points out that nobody in 1873 could have given the phrase "continuous communication" a literal interpretation "because no one believed that a boat could force its way through the ice of Northumberland Strait during the winter season."

52. $\quad R$. in right of Prince Edward Island v. R. in right of Canada, [1976] 2 F.C. 712 (T.D.), rev'd [1978] 1 F.C. 533 (F.C.A.), hereinafter P.E.I. Ferries. See also Re Minister of Transportation \& Public Works of Prince Edward Island and Canadian National Railway (1990), 7 I D.L.R. 596 (F.C.A.), in which the action was commenced by the province but a public interest intervener was accorded standing.

33. An act of God would excuse the federal govemment but not a strike, ibid. at 726 . 
On appeal, the Federal Court of Appeal unanimously confirmed that Canada had breached a justiciable statutory duty. ${ }^{54}$ In addition, Jackett C.J. and Le Dain J.A. held that the breach entitled the province to damages although their calculation was left to be determined at trial, in accordance with the agreement of the parties. Notwithstanding the ultimate success of the province, the precise basis of the claim is difficult to ascertain. The court seems to have rejected a contractual analysis ${ }^{55}$ founding itself instead on the breach of a statutory duty, but giving little explanation as to how this might form the basis of a claim in damages. Given the difficulties associated with statutory torts in Canadian ${ }^{l a w}{ }^{56}$ it may be best to view this case as establishing the sui generis nature of obligations under constitutionalized intergovernmental agreements.

Our concern however is with the possibility of a third-party claim. Could business operators who lost tourist business successfully claim damages from the federal government? Both courts were of the view that residents would have no cause of action. Cattanach J.'s view at trial ${ }^{57}$ was simply that, as a matter of construction, any duty which was owed, was owed not just to residents of Prince Edward Island, but to residents of Canada as a whole. The ferry was, he said, in a singularly inapt metaphor, a two-way street. Le Dain J.A. agreed with this ${ }^{58}$ and went on to point out that this also had consequences for the calculation of damages, for it followed that the Government could only claim for expenses or loss to the government itself and could not mount a claim for adverse effects on the province as a whole.

Pratte J.A. also saw the linkage between the two issues but drew quite a different conclusion which was bound up with his rejection of the broader issue of the claim for damages. Pratte J.A. concurred in the opinion of the majority that the Order in Council imposed a legal duty, but "it did not describe the duty ... as a duty owed toward the new Province or its Government." 59

It is, therefore possible [he continued] to conceive of that duty as one toward the public at large. In that perspective, in case of a breach, the right to be compensated should not be limited to the Government of the Province: it should... be granted to all persons suffering damage as a result of the breach. But this, I would find unacceptable.

$R$. in right of Canda v. $R$. in right of Prince Edward Island, [1978] 1 FC. 533 (F.C.A.) Although this holding is clear there are some suggestions in the judgements of both Jackett C.J. and Le Dain J.A., that the case had not been argued by the Attomey General for Canada as vigorously as they expected.

5s. In particular the Court rejected the applicability of State of South Australia v. The Commonwealth (1962), 108 C.L.R. 130 (H.C.A.), on the grounds that that case was concemed with an ordinary intergovernmental agreement whereas the present case concemed constitutional issues. See Le Dain J.A., at note 54, supra, at 587 and Jackett C.J., at 545, especially note 5.

s9. Ibid. at 576 
Thus, having peered around the floodgate doors, he quickly slammed them shut. Alternatively, he went on, if the duty was owed to the new Province, there would still be two reasons for not making a damages award. First, it could not be said that this had been contemplated by the parties at the time of the Union, ${ }^{60}$ and, second, the province itself would not suffer damages but only those people who were unable to use the service. $^{61}$

Rather different, were the reasons for rejecting the claims of third parties, given by the Chief Justice. He dealt with the issue in one of the many footnotes to his scholarly judgement. Expressing no final opinion, he doubted whether a claim might be brought by an inhabitant for losses suffered as an individual:

I am of opinion that the "obligee" is the "Province" - i.e. the mass of inhabitants of the geographical area whoever they may be from time to time. I do not see the obligations to the Province as a joint right of the individuals or as a right held in trust for them as individuals. I see an analogy to the "booty of war" case (Kinloch v. Secretary of State for India (1882) 7 App. Cas. 619 (H.L.) and to the case of reparations received by a country which is the successful party to a peace treaty. ${ }^{62}$

The P.E.I. Ferries decision is a striking case in many ways. First, it clearly affirms the justiciable nature of constitutional obligations which arise by way of agreement. It also supports a liberal interpretation of the Terms of Union which has more in common with the "treaty approach" of the Supreme Court of Canada in the Precious Metals case; an approach which, as we have seen, was rejected by the Privy Council in the same case. Second, the court, in characterizing the breach as a breach of a statutory duty, recognizes that principles of contract law, while perhaps appropriate to an "ordinary" intergovernmental agreement or contract, are not suited to constitutional obligations of this character. Finally, the court implicitly recognizes a distinction between constitutional clauses which impose obligations and those that act as a limitation on power. The former apparently do not give rise to rights which can be asserted by an individual in a court of law.

\section{The Newfoundland Terms of Union}

There are three reported decisions involving claims by third parties founded upon the Terms of Union and a fourth case which deals with the proprietary consequences of the Union. The first two cases are both quite inconclusive since neither plaintiff had a good

The evidence for this was that at the time of Union the governments did not even have a forum in which to assess legal liability let alone deal with damages questions. A somewhat broader claim was made, at trial, by Cattanach J. who simply held that the Constitution Act, 1867 did not contemplate actions in damages; see supra, note 52 at 736 .

o1. This sounds almost like a remoteness argument (regarding economic loss).

62. Supra, note 54 at 555, footnote 30. The other case his lordship had in mind was probably Civilian War Claimants Association v. R., [1932] A.C. 14 (P.C.). At 560, footnote 40, Jackett C.J. also dealt with the associated issue of damages. 
case on the facts. Their primary interest lies in the fact that the claims, both of which were commenced by petition of right against the Government of Canada in the Exchequer Court, involved monetary claims rather than a more straightforward constitutional claim of a limit on legislative authority.

The most useful of these two decisions is Samson v. $R .^{63}$ Samson's claim was that as a former employee of the Government of Newfoundland who was now employed by Canada, he was entitled to be paid a wage comparable with that paid to other federal employees elsewhere in the country. His claim hinged upon s.39(1) of the Terms of Union which provided that "Employees of the Government of Newfoundland in services taken over by Canada pursuant to the Terms of Union will be offered employment ... under the terms and conditions from time to time governing employment in those services ...."

The court held that the section would not bear the interpretation contended by Samson. Only two members of the court considered the juridical foundation of Samson's claim which seems to have been framed in two ways. First, Samson appears to have argued that the terms of union represented a contract between the people individually and collectively of Newfoundland and Canada. Mr. Justice Rand rejected that characterization out of hand. "The so-called contract was simply an agreement, a consensus, on the Terms on

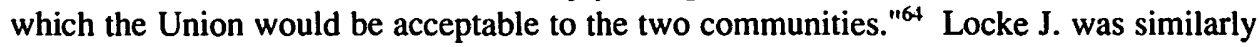
dismissive. The only contract in existence was the contract of employment and, in language redolent of the case law on privity, Samson was a stranger to the Terms of Union.

That was not the end of the discussion. Although the case was plead in contract, an alternative argument was made before the court based upon the statutory duty of the Government of Canada. Rand J. seems to have been well disposed to this argument but only accepted it for the purpose of disposing of the case on the merits. Locke J. did not believe that the argument was open to Samson at this stage of the case because, in his view, the Crown would surely have been able to plead estoppel had this been raised at trial. This is nothing more than dicta, with which Rand J. evidently did not agree, but it does illustrate a judicial tendency to jump from public law to private law doctrines in this area.

The second case, Pollock v. R., ${ }^{65}$ is even less helpful. Pollock's claim was that he was entitled to an increased pension based upon the language of s.39(1). He failed on the merits and therefore the court did not consider two arguments that had been addressed to it, namely that the court had no jurisdiction in the case, and that Pollock was not entitled to invoke the provisions of the Terms of Union.

63. [1957] S.C.R. 832.

64. Ibid. at 836; Rand J. did not refer to the jurisprudence of the court on the B.C. Terms of Union in reaching this rather minimalist conclusion.

65 [1956] Ex. C.R. 24. 
The most far reaching case under the Terms of Union was a reference case taken to determine the liability of a third party, Bowater's, to federal income tax. ${ }^{66}$ Prior to Confederation, Bowater's pulp and paper mill had been granted timber harvesting rights under the terms of a statutory agreement which exempted the company from tax. Following Confederation, the federal government purported to apply its income tax legislation to the company. The company, intervening in the reference, argued that its rights were not subject to unilateral change because of the terms of Article 18(3) of the Terms of Union which provided that:

Notwithstanding anything in these Terms, the Parliament of Canada may with the consent of the Legislature of the Province of Newfoundland repeal any law in force in Newfoundland at the date of the Union.

The majority of the Court found that subs.(3) was not the applicable provision because if it were given a wide interpretation the province would have an effective veto in all those cases, like the present, in which the subject matter of an old statute of the Dominion of Newfoundland was now split between the provincial and federal legislatures. All the members of the majority were of the view that the case fell under the more general clause, s.18(1), under which all laws in force in Newfoundland at the time of Union were subject to repeal either by the Parliament of Canada or by the Legislature of Newfoundland according to the authority of each under the Constitution Acts.

Only Mr. Justice Taschereau found for the company. In his opinion the statutory agreements were an entire package that had been granted to the company by the former unitary state. Different elements of the package were now within the competence of the federal or provincial governments but that did not permit Parliament to act unilaterally in the case of a mixed law such as the statutory agreement pursuant to which the company claimed its tax advantage. What was required here, in his opinion, was cooperative action by the federal and provincial governments pursuant to s.18(3) of the Terms of Union. No question seems to have been raised as to the right of the company to intervene in the case and claim the benefit of the constitutional provision. The case therefore simply supports the view, already seen in Jack, ${ }^{67}$ that the terms of a constitutionalized intergovernmental agreement will always be available to a third party as a defence to a public law liability.

The final case on the Terms of Union is Re Reid and March ${ }^{68}$ which establishes that the Terms acted as a conveyance binding on third parties. As such it adds little to the pronouncements of the Privy Council in Burrard Pow'er ${ }^{69}$ and the Precious Metals Case. $^{70}$

68.

69.

70.

Re Bowater's Newfoundland Pulp and Paper Mills, Limited, [1950] S.C.R. 608.

Supra, note 48.

(1965), 51 D.L.R.(2d) 186 (Nfld. T.D.).

Supra, note 42.

Supra, note 22. 


\section{The Natural Resources Transfer Agreements ${ }^{71}$}

(a) Introduction

The Natural Resources Transfer Agreements of 1930 effected the transfer of the administration and control of land, hitherto vested in the Crown in right of Canada, to the respective Crowns in right of the prairie provinces. In addition, the Railway Belt and Peace River Block were returned to British Columbia.

The Government of Canada's major concern in framing the agreement was to protect itself from claims which might be brought by the holders of rights to Crown lands. ${ }^{72}$ These rights included all manner of claims to public lands and mineral resources and included Indian rights to reserves and to hunt, based upon treaties with the Crown. In addition it appears that Canada wished to restrict the power of the provincial government to interfere with these vested rights.

Much of the Agreement in each case is therefore given over to a resolution of these problems. The basic solution adopted was to require the province to honour the terms of arrangements made by the Dominion with third parties and, in addition, to impose limitations upon the ability of the provincial legislature prejudicially to alter or affect the terms of federal leases and other arrangements. The result, as other commentators have noted ${ }^{73}$ is that these third parties obtained constitutionally entrenched property rights. Not surprisingly, the beneficiaries of those rights have been very willing to have them vindicated by the courts whenever they perceive an interference. In some cases however, not only have the rights of third parties been entrenched by the agreement, they have also been changed.

\section{(b) The Effect of Entrenchment of the NRTAs}

Entrenchment of third-party rights has occurred because of the limitations that the statutorily sanctioned ${ }^{74}$ agreements, impose on provincial legislative authority. The rights are not protected from federal legislative authority. A few examples will serve to illustrate the point. In Spooner Oils Ltd. v. Turner Valley Gas Conservation Board ${ }^{75}$ the plaintiff held a pre-1930 lease that had been granted by the Dominion. The lease gave

\footnotetext{
71. See generally, La Forest, supra, note 10.

72. Spooner Oils Lid. v. Turner Valley Gas Conservation Board, [1932] 4 D.L.R. 729 (Alta. S.C.) aff'd [1933] S.C.R. 629; Ewing J., at trial, at 745.

73. A. Thompson, "Sovereignty and Natural Resources - A Study of Canadian Petroleum Legislation" (1969) 4 U.B.C.L. Rev. 161, R. Harrison, "The Legal Character of Petroleum Licences" (1980) 58 Can. Bar Rev. 483.

74. In West Canadian Collieries Limited v. Attorney-General of Alberta, [1951] 1 W.W.R. 622 (Alta. S.C.), affd [1951] 3 W.W.R. I (A.C.A.), [1953] A.C. 453 (P.C.), McLaurin J. at trial at 626 makes the obvious but important comment that it was s. I of the British North America Act, 1930 rather than the agreement that limited the legislative powers of the province.

75. [1933] S.C.R. 629 .
} 
Spooner the right to conduct its operations on the leased lands in accordance with prevailing industry practices, which, at the time the lease was granted, allowed gas to be flared. In 1932, Alberta passed conservation legislation to regulate this practice and purported to apply it to the plaintiff. The Supreme Court of Canada held that the legislation affected the lessee in a way that was precluded by the NRTA. No issue seems to have been taken as to the entitlement of the plaintiff to raise this Agreement-based defence. $^{76}$

The cases on the Indian hunting rights clauses of the agreements are legion. The agreements subjected treaty Indians to provincial game laws but at the same time guaranteed them the right to hunt, trap and fish for food at all times of the year on unoccupied Crown lands. This has provided Indians with a simple and effective shield against much of the provincial game legislation which impose bag limits, closed seasons and the like. For example, in $R$. v. Sutherland ${ }^{77}$ Indians were charged with a breach of s. 19(1) of the Manitoba Wildlife Act. A further section (s. 49) deemed the area in which they were hunting to be occupied Crown lands within the meaning of the NRTA. The Supreme Court struck down this section on the grounds that by attempting to define a term in the Agreement, the province was purporting to arrogate to itself a unilateral right of amendment which could only be exercised by both parties in accordance with the Agreement. The court also indicated that this paragraph of the Agreement should be construed liberally because it protected treaty-based guaranteed hunting rights.

The Agreements have not been interpreted, however, as imposing any limitation on federal legislative power. This question arose and was decided by a badly divided Supreme Court in Daniels v. White and the Queen ${ }^{78}$. Daniels was charged with an offence under the Migratory Birds Convention Act and he pleaded the Manitoba NRTA in defence. The majority concluded that the relevant clause of the Agreement only contemplated a limitation on provincial laws. "The whole tenor of the agreement" stated Judson $\mathrm{J}^{79}$ "is that of a conveyance of land imposing specified obligations and restrictions on the transferee, not on the transferor." The majority also took refuge in the principle of interpretation that, in the event of an ambiguity, the court should select an interpretation that is consistent with the fulfilment of Canada's international obligations under the Migratory Birds Convention with the United States. arguments. The result in the case was clearly not in the public interest and the NRTAs were subsequently amended by the two governments to permit the application of conservation legislation. see S.C. 1938 , c. 36.

[1980] 2 S.C.R. 451, the court ruled that the legislation was also beyond provincial power because it was legislation in relation to Indians. For a more detailed review of the "Indian" clauses of the NRTAs see K. McNeil, Indian Hunting. Trapping and Fishing Rights in the Prairie Provinces of Canada (Saskatoon: University of Saskatchewan, Native Law Centre, 1983).

78. [1968] S.C.R. 517.

79. lbid. at 524 . 


\section{(c) Changes to Third Party Rights under the NRTAs: Limitation and Enhancement}

Third party rights were enhanced by entrenchment but one category of rights, Indian hunting rights have been enhanced in another way. Prior to the agreement Indian hunting rights were confined to the treaty areas of the respective tribes and bands. Under the terms of the Agreements however, all the Indians in a province are guaranteed the right to hunt for food at all times of the year on unoccupied lands and any other lands to which they have a right of access, whether within their traditional area or not. ${ }^{80}$ The same clause of the agreements has also been held to have curtailed Indian rights protected by treaty. In R. v. Horseman ${ }^{81}$ the Supreme Court of Canada found that the accused's rights to harvest wildlife commercially had been guaranteed by Treaty 8 but had been abrogated by the NRTAs insofar as the Indians were only exempt from provincial wildlife legislation while hunting for food. Counsel for Horseman had argued that since the Indians were not a party to the NRTA they could not have lost their rights by that means. The argument was rejected. The court relied upon s.1 of the Constitution Act, 1930 $0^{82}$ which, in their view, clearly indicated that the Agreement was intended to change the status quo and alter the distribution of powers.

Rights holders were also affected in one other way. Not only did the NRTAs allow them to look to the province for performance of the obligations owed by the Crown, but they also prevented them from proceeding against the Dominion. This was confirmed by the Privy Council in re Refund of Timber Dues. ${ }^{83}$ The main issue in that case was the liability of the Dominion and provinces, as between themselves, to make certain refunds to the holders of pre-emption records (referred to as entrants in the legislation). The Privy Council also took the opportunity to rule on whether the entrants could proceed at all against the Dominion or whether one of the parties to the original contract (the Dominion) had been replaced or substituted.

Lord Wright for the Privy Council began his judgement by referring to the NRTAs as contracts. ${ }^{84}$ He continued with the following comments: ${ }^{85}$ "It is clear that the agreement in itself in no way binds the entrant: he is not a party to it and so far his rights have not

This seems to be the result of Frank v.R., [1978] 1 S.C.R. 95 although this precise issue was not at stake. In $R$. v. Horseman, [1990] I S.C.R. 901, writing for the majority of the Supreme Court, Cory J. was of the view that Indian treaty rights were also enhanced by the immunity from provincial legislation that the Indians were accorded provided that they were hunting for food. This is a very doubtful claim, because treaty-protected rights were probably immune from provincial legislation by virtue of the exclusive right of the federal parliament to legislate for Indians and lands reserved for the Indians under s. 91(24) of the Constitution Act, 1867: R. v. White and Bob (1964), 52 W.W.R. 193 (B.C.C.A.), Davey J.A. at 198, aff'd [1965] S.C.R. vi. See also R. v. Stoney Joe, [1981] 1 C.N.L.R. 117.

lbid.

82. "The agreements set out in the Schedule to this Act are hereby confirmed and shall have the force of law notwithstanding anything in the British North America Act..."

83. [1935] A.C. 184 (P.C.).

s. Ibid. at 194.

8s. Ibid. at 197-98. 
been in any way affected." Neither would the mere fact of statutory confirmation necessarily change this position. However, looking at the arrangement as a whole and noting that the Dominion no longer had any rights over the land, the only reasonable conclusion, in his Lordship's view, was that the agreement, once approved by Imperial legislation, must have effected a statutory novation.

\section{Conclusions}

Several conclusions can be drawn from the case law on the NRTAs and the other constitutionalized agreements discussed above. First, the cases confirm that where a constitutionalized agreement can be construed as a limitation on legislative power, an affected third party will be able to plead the agreement in defence to criminal or quasicriminal charges. ${ }^{86}$ It may also be used by third parties to vindicate a proprietary or contractual right. ${ }^{87}$ Second, a constitutionalized agreement, either expressly or by necessary implication, may bring about a unilateral change in the contractual rights of third parties. ${ }^{88}$ Third, where a clause in a constitutionalized agreement takes the form of an obligation rather than a limitation on power it seems unlikely that third parties will be entitled to enforce the obligation or claim damages for its breach. ${ }^{89}$ Fourth, because constitutionalized agreements can be used to effect not only transfers of property but also legislative control, third parties may be incidentally affected in all sorts of ways. ${ }^{90}$ Finally, the courts have not articulated a consistent view of the status of constitutionalized agreements although they certainly believe them to be justiciable. They have variously called them treaties, constitutional compacts, commercial arrangements, contracts and "simply an agreement, a consensus." As a result, principles of both public and private law have been discussed and applied. By the same token neither have the courts been consistent on the interpretive approach to take. On the one hand the Privy Council has interpreted the agreements as a commercial contract ${ }^{91}$ while others have suggested a more liberal interpretation on the grounds that constitutional obligations are at stake. ${ }^{92}$

Jack v. R., supra, note 48, R. v. Sutherland, supra, note 77.

Spooner Oils, supra, note 72, see atso the recent decision of the Supreme Court of Canada in Canada (Director of Soldier Settlement) v. Snider Estate, [1991] 5 W.W.R. 289 (S.C.C.).

In re Refund of Timber Dues, supra, note 83, Horseman v. R., supra, note 80.

P.E.I. Ferries, supra, note 52.

Burrard Power v. R., supra, note 42.

Notably in the Precious Metals case, supra, note 22. See also the majority decision of the Supreme Court in the Daniels v. White and the Queen. supra, note 78.

Notably the P.E.I. Ferries case, supra, note 52, the B.C. Railway Case, supra, note 23 and, most recently. Snider Estate, supra, note 87. Sutherland, supra, note 77 is explainable on the grounds that the particular paragraph in question was designed to protect Indians, see also the dissenting judgment in Horseman, supra, note 80. 


\section{B. AUSTRALIAN CASE LAW ON THE FINANCIAL AGREEMENT}

\section{Introduction}

Since there is only one constitutionalized agreement in Australia the relevant case law is limited although the litigation that the Financial Agreement has engendered has been of high constitutional importance.

The coordination of borrowing between the states had been a source of some difficulty before federation and the problem was not resolved in $1900 .{ }^{93}$ Discussion on the topic occurred sporadically after federation and was joined with discussion about the possibility of the Commonwealth assuming all state debts. A voluntary loan council was established in 1923 and this paved the way for an agreement in 1927 which was formalized when a constitutional amendment authorizing what is now s.105A was approved by the electors and the state legislatures. The text of s.105A is as follows:

(1.) The Commonwealth may make agreements with the States with respect to the public debts of the States, including.

(a) the taking over of such debts by the Commonwealth;

(b) the management of such debts;

(c) the payment of interest and the provision and management of sinking funds in respect of such debts;

(d) the consolidation, renewal, conversion, and redemption of such debts;

(e) the indemnification of the Commonwealth by the States in respect of debts taken over by the Commonwealth; and

(f) the borrowing of money by the States or by the Commonwealth, or by the Commonwealth for the States.

(2.) The Parliament may make laws for validating any such agreement made before the commencement of this section.

(3.) The Parliament may make laws for the carrying out by the parties thereto of any such agreement.

(4.) Any such agreement may be varied or rescinded by the parties thereto.

(5.) Every such agreement and any such variation thereof shall be binding upon the Commonwealth and the States parties thereto notwithstanding anything contained in this Constitution or the Constitution of the several States or in any law of the Parliament of the Commonwealth or of any State.

(6.) The powers conferred by this section shall not be construed as being limited in any way by the provisions of section one hundred and five of the Constitution.

Statutory approval of the arrangements was involved at all stages of the process and because it is of significance for subsequent litigation we shall outline the pattern of Commonwealth legislation here. Upon the agreement being reached in December 1927 it was approved by the Financial Agreement Act, 1928. Following the successful constitutional amendment in 1929 the Commonwealth passed the Financial Agreement

9.. For the background see S. Davis, "A Unique Federal Institution" (1951-53) 2 Univ. of W.A.L. Rev. 350 and C. Saunders supra, note 8. Saunders also provides details of the practical and perhaps lcgal demise of the Loan Council. 
Validation Act which scheduled the agreement to the statute and "hereby validated" it. Subsequent amendments to the Financial Agreement were all approved by statutes with the title "Financial Agreement Act."

Amongst other things, the agreement established the Australian Loan Council and provided that monies should not be borrowed by the Commonwealth or any state except in accordance with the agreement. The Commonwealth took over the debts of the states but the states were required to pay the Commonwealth a portion of the interest payments and to contribute to the maintenance of a sinking fund.

\section{The Garnishee Case}

Several important cases have raised, directly or indirectly, the effect of the Financial Agreement and s.105A. It was not long before the agreement met its first test when New South Wales defaulted on its interest payments. ${ }^{94}$ The Commonwealth took steps to protect itself and passed the Financial Agreement Enforcement Act. The Act was a farreaching measure which allowed the Commonwealth to recover monies which its Auditor General considered to be owing to it under the Agreement. In particular the Commonwealth was allowed to recover these monies directly from taxpayers in the state. The usual judicial procedures could be avoided in emergency circumstances leading Evatt J. to refer to the Commonwealth acting as "plaintiff, judge and executioner." took its case to the High Court and questioned the validity of the Enforcement Act.

It will be apparent that the litigation, which upheld the legislation, did not raise the question of the rights or obligations of third parties under the agreement except in the most indirect sense that the Commonwealth legislation purporting to "carry out" the agreement allowed recovery from third-party taxpayers. The agreement itself certainly had not provided for this in terms. Nevertheless, their Honours did make some observations about the status of the Financial Agreement and on the effect of s.105A of the Constitution which formed the foundation of litigation in subsequent cases.

Of the two dissenting judges, Gavan Duffy C.J. and Evatt J., only the Chief Justice offered any explicit comments on the status of the agreement and its relationship to s.105A: "If the Commonwealth and the States have in fact made an agreement the subsection makes that agreement valid though the parties or some of them had in fact no authority to make the agreement; ... It [s.105A(5)] does not alter the nature or incidents of the agreement, or affect the rights, obligations and duties of the parties under the agreement ..."96 Furthermore, subs.(3), in his view, was not apt for enforcing

\footnotetext{
94. The circumstances behind this are discussed in C. Saunders, supra, note 8. Briefly, New South Wales believed that the crisis wrought by the Depression should be handled by defaulting on overseas debt payments.

95. New South Wales v. The Commonwealth (No. I) (1932), 46 C.L.R. 155 (H.C.A.), hereinafter the Garnishee Case, per Evalt J. (dissenting) at 195.

$\%$

lbid. at 172 .
} 
obligations, still less for authorizing a recovery from taxpayers who are not parties to the agreement.

The majority gave considerably more weight to the effect of s.105A. Per Rich and Dixon JJ: "In our opinion the effect of this provision is to make any agreement of the required description obligatory upon the Commonwealth and the States, to place its operation and efficacy beyond the control of any law of the seven Parliaments, and to prevent any constitutional principle or provision operating to defeat, or diminish or condition the obligatory force of the Agreement. ${ }^{197}$

Starke J. offered an opinion in the same vein: "the Financial Agreement ... is part of the organic law of the Commonwealth ... It creates rights and duties as between the Commonwealth and the States upon and in respect of which the judicial power of the Commonwealth can be exerted."98 McTiernan J. was the most effusive: "The imperious character of the language employed in this sub-section of the Constitution, in my opinion, renders certain the paramount force of any Financial Agreement to which the sub-section applies ... It ... raises the obligations, which the agreement fastens upon the parties, to the level of an obligation arising out of the Constitution itself ... it [ss. 105A(5)(a)] pulsates with the vitality of the Constitution itself and imbues with the force of a fundamental law any agreement to which it applies." 99 Finally, he stated that the "Agreement is not a mere political engagement but a contract of strict legal obligation, and... a breach of the Agreement gives rise to a justiciable matter." 100

\section{The State Banking and Bank Nationalization Cases}

The Financial Agreement next came up for consideration in Melbourne Corporation v. Commonwealth ${ }^{101}$ when several members of the bench, of their own motion, considered the limiting effect of the Agreement. The issue in the case was whether or not the Commonwealth could require a municipal corporation, an entity created by the state, to do its banking with the Commonwealth Bank rather than a "private" bank. Chief Justice Latham, who raised the issue, ${ }^{102}$ was of the view that Part I.(5) of the Agreement had the effect of allowing states and state institutions to borrow from banks for temporary purposes by way of overdraft and other similar arrangements. That right could not be interfered with by the Commonwealth parliament because of s.105A(5). Williams J. agreed, stating that prior to the Financial Agreement the states had been able to deal with private banks and that right had effectively been assured to them by the agreement. ${ }^{103}$ Of the other members of the bench, only McTiernan J. dealt with the issue, disposing of

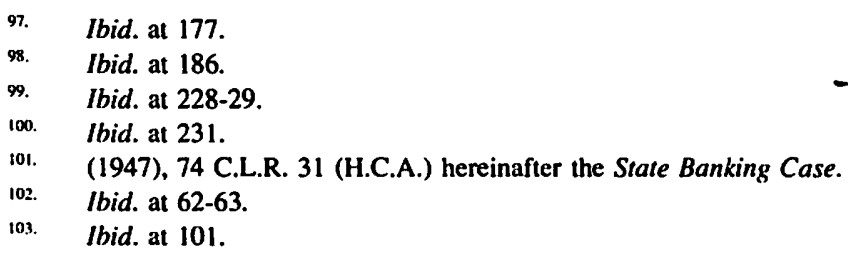


the argument in characteristically trenchant terms. In his opinion, all that the agreement guaranteed were the means available to a state to raise money. It had nothing to say about from whom a state could borrow and certainly could not be interpreted as giving a state the right to borrow from whatever bank it chose. ${ }^{104}$

Having failed to perceive an argument once, the states were not to be caught a second time and the potential application of the Financial Agreement as a limitation on power was fully argued in Bank of New South Wales v. Commonwealth. ${ }^{105}$ The point seems to have been argued, perhaps wisely, only by the plaintiff states and not the plaintiff banks. The issue in the case was whether the Commonwealth's bank nationalization measures were beyond power inter alia because of the Financial Agreement. The argument was framed very much in contractual terms the precise ground being the principle stated in Southern Foundries v. Shirlaw ${ }^{106}$ that one party to a contract should not do anything that would render the contract impossible of performance. Williams J., joined this time by Rich J., stuck to the opinion that he had expressed in the State Banking Case. In their Honours' opinion, the states were entitled to a banking system as it stood at the time of the Financial Agreement. Consequently, because of s.105A, and because this matter did not rest on contract alone, the federal legislation was invalid to the extent that it was inconsistent. ${ }^{107}$ All the other members of the court shrank from that conclusion and successfully distinguished the State Banking Case.

In Dixon J.'s view ${ }^{108}$ the Financial Agreement might have assumed the existence of a banking system but it guaranteed nothing more than a right to borrow from whatever institutions were in place at a particular time. Starke J. ${ }^{109}$ was of the view that the State Banking Case could be distinguished because there was no element of compulsion here and a state could always establish its own bank, thereby preserving the temporary overdraft arrangements of the type contemplated by the Agreement. McTiernan J. stuck to the view he had expressed in State Banking and held that the Financial Agreement did not explicitly entrench the banking system and there was no basis for implying entrenchment. ${ }^{110}$

Neither of these cases can be considered to be clear-cut. Only three judges dealt with the Financial Agreement issue in State Banking and while the entire bench discussed the point in the Bank Nationalization Case only two members of the court thought that the argument had any merit. It is notable, however, that the entire court explicitly or inferentially conceded the point that the Financial Agreement, supported by s.105A, could,

Ibid. at 95. Dixon J. at 84-84 did refer to the Financial Agreement but not for the purpose of suggesting that it might have imposed a limit on federal power in this case. His contention was that the agreement could not be used to authorize what had happened here.

105. (1948), 76 C.L.R. 1, hereinafter the Bank Nationalization Case.

106. [1940] A.C. 701 .

107. (1948), 76 C.L.R. 1 at 281 to 282.

108. Ibid. at 338-9.

109. Ibid. at 325 to 326 .

110. Ibid. at 397. 
in principle, constitute a limit on Commonwealth power. Whether the argument would be available at the suit of a third party has not been considered.

\section{Sankey v. Whitlam}

The final case, Sankey v. Whitlam,"' comes much later in the life of the Agreement and some of the more enthusiastic language of the court in the Garnishee Case seems to have been almost embarrassing to the High Court of the 1970s. The case raised equally significant constitutional questions. Sankey laid a private information against Whitlam, a former prime minister, and other former members of his cabinet, alleging a conspiracy to effect a purpose that was unlawful under a law of the Commonwealth and therefore an offence under the Commonwealth Crimes Act.

The particular breach alleged was a breach of the Financial Agreement requirement that all Commonwealth borrowing be in accordance with the Agreement. A conspiracy to breach the Constitution Alteration (State Debts) Act (sic) and the Financial Agreement Act was also alleged. A separate charge alleged a further conspiracy to deceive the Governor General into believing that the loans in question were temporary when they were in fact not so, in breach of the Agreement and the above statutes.

The matter reached the High Court where much of each of the judgements focuses on matters of Crown privilege. The court reached the remarkable conclusion that, of all the documents for which discovery was sought (including cabinet documents), only the Loan Council documents should be protected. ${ }^{112}$ The court also had to address itself to the question of whether or not the provisions of the Loan Agreement could be said to be a law of the Commonwealth within the meaning of the Crimes Act. Hence the court raised in a very direct way the effect of the Agreement on third parties: was it an objective public law, creative of obligations for third parties including Ministers of the Crown, or was it merely a contract?

The court answered firmly and unequivocally, that it was the latter although the Court did acknowledge that the Commonwealth could have used its powers under s.105A(3) of the Constitution to make a breach of the agreement an offence. Not surprisingly it had some difficulty dealing with the effusive language which the majority of the court had used in the Garnishee case, but that was dealt with by the asseveration that in the earlier case the court had not addressed itself to this particular problem.

III. (1978), 142 C.L.R. I (H.C.A.). The background to the case is intimately connected with the notorious dismissal of the Whitlam government by Govemor-General Kerr, see C. Saunders, supra, note 8 at 197-199.

112. See C. Saunders, supra, note 8 at 200. The governmental interest in the secrecy of these documents surely undermines the court's view of the Financial Agreement as merely a matter of contract. 
With the exception of Jacobs $\mathrm{J}^{113}$ all the members of the Court gave detailed and separate consideration to the status of the Agreement and the various statutes designed to validate or ratify it.

The Agreement itself seems to have caused the court the greatest difficulty, perhaps because of the earlier decisions. Nevertheless, all members of the Court who addressed the matter thought that the Agreement was not a law of the Commonwealth. Gibbs A.C.J. devoted the most attention to the problem. In his view:

It is true to say that the Financial Agreement has the force of law even of an organic law, so far as the Commonwealth and the States are concerned. However it does not create rights or impose duties on other persons; it is binding by s.105A(5) only on the Commonwealth and the States. Notwithstanding s.105A(5) I do not think it accurate to describe the Financial Agreement as a law. It is in truth sui generis... even if it could be described as a law it is not a law of the Commonwealth, because it is not made by or under the authority of the Parliament of the Commonwealth. ${ }^{114}$

There was also consensus on the effect of the validating and approving statutes; they were not aptly framed to transform something that was not a law of the Commonwealth into such a law. The court discerned in the case law ${ }^{115}$ a distinction between statutes that merely validated or approved an agreement and statutes that incorporated the agreements into the text of the statute and gave each clause the effect of a statutory provision. In the case of the approving statutes the members of the court were of the view that they merely served the function of fulfilling a condition precedent to the validity of the agreement. ${ }^{116}$ In a similar vein, the validating Act was merely concerned retrospectively to validate the agreement by giving it the benefit of the constitutional protection accorded by $\mathrm{s.105 \textrm {A } .} .^{117}$

Finally, the Constitution and the constitutional amendment, as two potential sources of objective vitality were readily dismissed by the Court. The Constitution itself was more than a law of the Commonwealth and the same was true of any amendment, a point which was textually confirmed by the fact that an amendment does not include the term "Act" in its title ${ }^{118}$ and by the reference to the electors in the enacting clause. In addition,

113. Supra, note 111, at 102, Jacobs J. merely stated that no offence was disclosed.

114. Ibid. at 30 [emphasis added]. See also Stephen J. at 74.

115. The cases particularly relied on were R. v. Midland Railway Co. (1887), 19 Q.B.D. 540. Manchester Ship Canal Co. v. Manchester Racecourse Co., [1901] 2 Ch. 37, Pyx Granite Co. v. Minister of Housing and Local Government, [1960] A.C. 260 (P.C.), Caledonian Railway Co. v. Greenock and Wemyss Bay Railway Co. (1874), L.R. 2 Sc. \& Div. 347 (H.L.).

116. Members of the court referred here with approval to Placer Development Lid. v. Commonwealth (1969), 121 C.L.R. 353 (H.C.A.). I have dealt with this issue in more detail in the companion paper referred to in note 1 , supra.

117. Supra, note 111 , Mason J. at 91 and Stephen J. at 77.

118. Ibid. Stephen J. at 75. 
s.105A never changed the status of the agreement, it merely left it as a contract binding the parties. ${ }^{119}$

The precise terms of the Commonwealth Crimes Act provided an easy way out for the High Court in Sankey but one can, I think, still legitimately ask the question: is executive behaviour in breach of the Agreement unlawful? What would have been the result, setting aside problems of standing, ${ }^{120}$ had Sankey asked for a declaration framed in those terms? That would have posed the issue in a bald way, for the Court would have to determine whether the agreement was a public or a private law arrangement and it could not have hidden behind the narrow technical question "is the agreement a law of the Commonwealth."

Sankey was followed by Mason J. dismissing an application for an interlocutory injunction in Tasmanian Wilderness Society Inc. v. Fraser. ${ }^{121}$ The plaintiffs sought an injunction against the prime minister and federal treasurer who were to attend a loan council meeting to restrain them from voting in favour of borrowing to be used by the State electricity agency of Tasmania to dam the Franklin River. The plaintiff was relying upon the federal Heritage Act and the Environmental Protection Act but to make the case had to establish that the loan council was an "authority of the Commonwealth," "established by or appointed under the laws of the Commonwealth." Mason J. rejected this contention holding that the loan council was established by contract and not by statute. In reaching this conclusion Mason seems to have considered that the point was established by Sankey v. Whitlam.

\section{Conclusions}

The case law on the financial agreements justifies the following conclusions. First, the agreement does have some constitutional effect and must act as a limitation on legislative power. One commentator ${ }^{122}$ has suggested that Sankey is inconsistent with this but it must be remembered that this was not the issue in Sankey and in the earlier decisions of the Court, where limitation on power was an issue, not one member of the Court rejected, in principle, the argument that the Agreement, in combination with s.105A, could operate as a constraint on power. Consequently, an individual should be able to seek the benefit of the agreements in an appropriate case. Both Sankey and Fraser can be explained on the basis that the conclusion turned in each case on the particular language used in Commonwealth legislation. Second, unlike the Canadian examples, s. 105A makes it clear

119. Ibid. Mason J. at 90.

120. I have not attempted to discuss standing in this paper. Obviously standing would be a serious problem in Australia even in a constitutional case. Standing can be justified on the basis that the public has an interest in the lawful and constitutional behaviour of governments. This approach has found favour with the Canadian courts and the issue is discussed in more detail in an excursus in the paper referred to in note 1.

121. (1982), 153 C.L.R. 270 (H.C.A.).

122. C. Saunders, supra, note 8 , at 212 , suggests that Sankey is authority for saying that the Financial Agreement is merely a contract and not a constraint on power. 
that the Agreement does not form part of the Constitution, while the statutory approval language falls short of turning the arrangement into a set of statutory duties. However, the language of subs.(5) cannot be ignored and the agreement must bind the Commonwealth and state governments.

\section{CONCLUSIONS}

My concerns as to the constitutional protection of intergovernmental agreements are two-fold. First, the simple longevity of these agreements, combined with their detail, raises questions as to their suitability in a different age, and in different technological circumstances. Second, while in some circumstances, the agreements may serve a progressive function and confer much needed rights on certain sectors of society, they may just as readily confer unintended rights or disabilities on others.

The constitutionalized agreements of both countries have been developed to deal with different historical circumstances. In Canada in particular the result has been a patchwork of constitutionalized provisions. For example, it is not clear why Indians in the Prairie provinces should be entitled to the benefit of a constitutionally protected hunting right while the same right was, until $1982,{ }^{123}$ denied to Indians resident in British Columbia. It is even more mystifying to see selected corporate entities like the plaintiff in Spooner Oils claiming the benefit of constitutionally protected property rights. Where, one may ask, does reason lie when British Columbia is entitled to insist upon the maintenance of branchline railroads while other provinces must bow to the decisions of the federal government made in the national interest and based upon the economic exigencies facing the country?

In Australia, there has not been the same tendency to make special deals for individual states ${ }^{124}$ but citizens may be forgiven for wondering why it is that some states indulge in lease-back transactions and other weird and wonderful financial arrangements in order to raise capital. The answer lies not in reasons of economic efficiency but in an attempt to avoid the strictures of the Financial Agreement.

Intergovernmental agreements are an inevitable part of modern co-operative federalism ${ }^{125}$ and in some cases the parties may well wish, in the interests of certainty for example, to ensure that particular arrangements should survive a change of government. The case law described above, however, suggests that there are considerable risks and disadvantages associated with "constitutionalizing" an agreement. Part of the difficulty lies in the fact that these agreements are rarely drafted as if they were to

123. Constitution Act, 1982, s.35, quoted supra, note 5.

124. Any attempt to do so would have to sidestep a whole battery of constitutional provisions prohibiting discrimination between states: ss. 51(ii), 51(iii), 88, 92, 99 \& 102. Some attempts however have succeeded based upon 5.96, the most notorious case being W.R. Moran Proprietary, Limited v. Deputy Commissioner of Taxation (N.S.W.), [1940] A.C. 838 (P.C.).

125. See the paper referred to in note 1 , supra. 
become constitutional provisions; they often, as the Privy Council indicated on a number of occasions, bear a greater resemblance to commercial transactions rather than arrangements of high constitutional importance. Constitutions typically are more spartan and are drafted in a way which invites an interpretation as a living tree that may mature and change over time. Once agreements are constitutionalized it is clear that they will not be easy to amend. Consequently they should be instruments of last resort in any choice of means to meet a particular policy goal, unless they are accompanied by a sunset or review clause. ${ }^{126}$

It is interesting in this context to consider the form which was devised for federalprovincial immigration agreements in the Meech Lake Accord. ${ }^{127}$ It was proposed that such agreements could have the force of law and would only be amendable either by resolutions of the provincial legislative assembly, the Senate, and the House of Commons or by a method provided in the agreement. Several checks were envisaged for these agreements. First, it was provided that an agreement would only have the force of law (and therefore affect third parties) where a proclamation to that effect had been issued by the Governor General on the authorization of resolutions from the Senate, House of Commons and the provincial legislative assembly. Second, agreements with the force of law, and governmental actions taken pursuant to them, were to be subject to the Charter of Rights and Freedoms and finally, such agreements would have effect only for so long as they were not repugnant to a federal statute setting national standards and objectives.

The failed Meech proposals may provide a useful model in the event that either jurisdiction elects to resort to constitutionalizing an intergovernmental agreement in the future. Further protections, such as periodic review, might also be suggested. Special attention should be given to agreements which may act as a limitation on power. In the case of the proposed Meech agreements any limitation on power would seem to be confined to laws intended to amend the agreement. In this respect the proposed agreements are closer in design to the Australian Financial Agreement than existing Canadian models, since the resulting agreements will not be part of the Constitution; the Constitution would merely have prescribed their constitutional effect.

Some of these concerns also extend to the constitutional protection of aboriginal land claim agreements in Canada. On the one hand I subscribe to the view that fundamental aboriginal rights ought to be protected in perpetuity and should constitute a limitation on legislative power, but on the other hand 1 express considerable scepticism that the entire detailed text of agreements several hundred pages in length, (rather than a charter of aboriginal rights) should be entitled to perpetual constitutional protection. To be specific, my concern here would be with the longevity of the detail, rather than the special protections which are afforded, or their effect on non-parties. 